\title{
Edumol: Avoin ja ilmainen molekyylimallinnussovellus kemian opetuksen tueksi
}

\section{Johannes Pernaa}

Edumendo Oy,johannes.pernaa@edumendo.fi

Tiivistelmä Edumol on kemian opetuksen tueksi suunniteltu avoin ja ilmainen verkkopohjainen molekyylien mallinnus- ja visualisointiympäristö,joka toimii kaikilla päätelaitteilla. Se on rakennettu Jsmol-kirjaston päälle, joka on avoimen lähdekoodin JavaScript-kirjasto molekyylien visualisointiin. Edumol tarjoaa monipuolisen kemian opetuksen visualisointiympäristön, jossa kaikki toiminnot on suunniteltu kemian opetuksen tutkimuksen avulla. Edumolilla voi rakentaa molekyylejä itse tai hakea niitä suoraan rakennetietokannoista, kuten esim. Protein Data Bank, NCI ja PubChem. Rakenteet voi optimoida molekyylimekaniikkatasolla ja niitä voi visualisoida eri molekyylimalleilla. Sovelluksella voi mitata sidospituudet ja sidoskulmat, laskea osittaisvaraukset ja visualisoida molekyylien elektrostaattiset potentiaalipinnat. Verkossa tehtävän visualisoinnin lisäksi Edumolilla voi myös tallentaa työn tiedostona, kuvana, 3D-mallina tai molekyylitiedostona, joita voi jatkomuokata myöhemmin Edumolissa, toisissa ohjelmistoissa tai $3 \mathrm{D}$-tulostaa.

\section{Johdanto}

Molekyylimallinnus on ollut yksi kemian opetuksen tutkituimmista tieto- ja viestintätekniikan (TVT) sovellusalueista jo yli 20 vuoden ajan. Aiheesta on kirjoitettu valtavasti kansainvälisellä tasolla, mutta myös kotimaan kemian opetuksen tutkimuksessa molekyylimallinnus on ollut erittäin keskeinen aihe. Suomessa molekyylimallinnusta kouluopetuksessa on tutkittu ja sovellettu opetuksessa 2000-luvun alusta lähtien (Aksela \& Lahtela-Kakkonen, 2001).

Alan tutkimuksissa on selvitetty muun muassa, miten molekyylimallinnus tukee kemian oppimista, miten opettajat ja oppilaat suhtautuvat työmenetelmään ja mitkä kemian aiheet sopivat mallinnettavaksi kouluopetustasolla. Kirjallisuuden mukaan on selkeää näyttöä siitä, että molekyylimallinnus tukee kemian oppimista ja sitä pidetään yleensäkin modernina ja motivoivana työtapana. Molekyylimallinnus auttaa esimerkiksi oppilaita kehittämään submikroskooppisen tason mentaalimalleja, mikä tukee ilmiöiden syy - ja seuraussuhteiden ymmärtämistä ja selittämistä. (Aksela \& Lundell, 2008)

Kemian oppimistutkimuksen lisäksi aiheen parissa tehdään poikkitieteellistä sovelluskehitystä. Alan sovelluskehitys yhdistää kemian opetuksen tutkimukseen perinteisiä ja soveltavia kemian tutkimusaloja (esim. orgaaninen kemia, laskennallinen kemia ja keminformatiikka) ja tietoteknistä kehittämistä (esim. tietokannat, käyttöliittymät ja grafiikan visualisointi). Kehittämistä tehdään sekä kaupallisesta että avoimesta näkökulmasta. Tunnettuja avoimia projekteja ovat esimerkiksi Jmol (Jmol, 2015), Protein Data Bank (RCSB PDB, 2015) ja PubChem (NCBI, 2015). Mainituista projekteista Jmol on molekyylien visualisointiohjelmisto, Protein Data Bank ja PubChem ovat 
tietokantapalveluja. Myös Suomessa tehdään jonkin verran alan sovelluskehitystä. Tässä artikkelissa esitellään Edumol-verkkopalvelun kehittämistyö ja tarkastellaan, millaisia mahdollisuuksia se tarjoaa kemian opetuksen ja oppimisen tueksi (Edumol, 2015).

\section{Edumolin historia ja keskeiset teknologiat}

Edumol on avoin ja ilmainen molekyylimallinnusverkkosovellus. Sen kehitystyö alkoi jo vuonna 2009, ja palvelun ensimmäinen versio julkaistiin kemian vuotena 2010 (Pernaa \& Aksela, 2011). Ensimmäinen versio poistui käytöstä kuitenkin hyvin nopeasti, sillä se rakennettiin Java-ohjelmoinnilla toteutetulla Jmol-kirjastolla (Jmol, 2015). Java-ratkaisut verkkoteknologiana vanhentuivat vuonna 2010, jolloin julkaistiin ensimmäinen iPad-tablet. iPad:n verkkoselain ei tukenut raskaita ja tietoturvaltaan haavoittuvaisia Java-appletteja, joihin vanhan Edumolin molekyylimallinnustyökalut pohjautuivat. Palvelun kehittämisen näkökulmasta tilanne oli melko ikävä, koska se oli kehityksen huipulla vain muutaman kuukauden. Suomen oppilaitoksiin iPadit ja muut tabletit saapuivat toki vasta hieman myöhemmin. Koulujen opetusteknologiavalmiuksien näkökulmasta analysoituna palvelu vanhentui noin kahdessa vuodessa tablettien yleistymisen seurauksena. (Pernaa \& Aksela, 2013)

Pian tablettien saapumisen jälkeen kävi ilmi, että mobiililaitteet tulevat yleistymään kouluissa nopeasti (Pernaa \& Aksela, 2013). Tämä vauhditti sekä molekyylimallinnuksen avoimen lähdekoodin sovelluskehitysyhteisöä että myös yleisen mobiiliyhteensopivan verkkosovelluskehityksen kehittymistä. Vähitellen alkoi syntyä Javattomia JavaScriptpohjaisia ratkaisuja sekä molekyylimallinnuksen että mobiiliteknologioiden puolelle.

Edumolin uusi versio julkaistiin kesällä 2014. Uudistuksen kehittämisessä vierähti monta vuotta, sillä palvelun uudistamisessa jouduttiin odottamaan avointen ratkaisujen kehittymistä, joiden päälle Edumol lopulta päätettiin rakentaa. Edumol koostuu:

1. 3D-visualisointiympäristöstä, joka on rakennettu Jsmol-kirjaston avulla (JSmol, 2015).

2. 2D-rakennustyökaluista, jotka on rakennettu integroimalla palveluun JSME-kirjasto (Bienfait \& Ertl, 2013).

3. Kosketusnäyttöoptimoidusta responsiivisesta käyttöliittymästä, joka tukee suomen ja englannin kielen käännöksiä. Käyttöliittymä on rakennettu JQuery Mobile kirjastolla (The jQuery Foundation, 2015).

Tarkastellaan seuraavaksi tarkemmin JSmol- ja JSME-kirjastoja, sillä ne ovat Edumolin ominaisuuksien kannalta keskeisimmät teknologiat.

\section{$2.1 \mathrm{JSmol}$}

Edumolin 3D-visualisointitoiminnallisuudet on kehitetty JSmol-kirjaston avulla. JSmol on JavaScript-kirjasto, joka mahdollistaa Javattoman interaktiivisen kemiallisten rakenteiden 3D-visualisointiympäristön kehittämisen. JSmol on Jmol-projektin sivuprojekti, joka syntyi mobiililaitteiden yleistymisen seurauksena vuonna 2012. Projekti käynnistyi aikoinaan 
vauhdikkaastija kehittäminen oli heti globaalia. Ensimmäisen demoversion valmistumiseen meni aikaa vain pari kuukautta. Vauhdista kertoo myös se, että kehittäjät työskentelivät verkon välityksellä itsenäisesti eri mantereilla, eivätkä he olleet koskaan edes tavanneet toisiaan. (Hanson, 2012)

JSmol-projektin käynnisti professori Robert Hanson St. Olaf Collegesta Yhdysvalloista. Prof. Hanson on yksi isäntäprojekti Jmol:n pääkehittäjistä. Hanson julkaisi JSmol:n ensimmäisen version Jmol-kehittäjien postituslistalle innostusta puhkuvalla saatekirjeellä (13.10.2012), jossa hän kuvailee projektin alkuvaiheet, onnistumiset ja haasteet. Ensimmäinen versio oli melko raaka juuri toimiva versio, jota hän kehotti kirjeessä testaamaan ja tutkimaan. Hanson nimesi sovelluksen JSmol:ksi. Nimen hän johti Jmol:sta. JSmol lyhenne tarkoittaa Java-less Jmol. Vaikka työ oli vasta alussa, niin toimivan demoversion aikaansaaminen ja siitä nouseva innostus ja ylpeys, oli käsin kosketeltavaa. (Hanson, 2012)

Ensimmäinen versio oli lähes käyttökelvoton pedagogisille sovelluskehittäjille. Se oli niin hidas, että molekyylien latautuminen kesti lähes minuutin. Nopean alun jälkeen JSmol:a kehitettiin suhteellisen hitaasti, ja ensimmäinen sulavasti toimiva versio julkaistiin vasta vuoden 2014 alussa. Edumolin uudistaminen aloitettiin heti julkaisun jälkeen keväällä 2014, ja versio 1.o julkaistiin 12.6.2014. (Edumol, 2015)

\subsection{JSME}

JSME on ilmainen ja avoin JavaScript-pohjainen molekyylieditori. Se on kehitetty edeltäjänsä Javapohjaisen JME:n pohjalta vastaamaan mobiililaitteiden HTML5vaatimuksia. JSME sisältää toiminnoiltaan monipuolisen molekyylieditorin, mutta sen käyttöliittymää ei ole optimoitu kosketusnäytöille. Se ei ole responsiivinen vaan sen painikkeet ovat samankokoisia päätelaitteen koosta riippumatta (ks. kuva 1). JSME on rakennettu hyvin avoimeksi sekä teknologian että lisenssin näkökulmasta. JSME:tä voi helposti integroida erilaisiin verkkosovelluksiin, ja se onkin suoraan integroitu myös JSmolkirjaston sisälle. (Bienfait \& Ertl, 2013; JSmol, 2015)

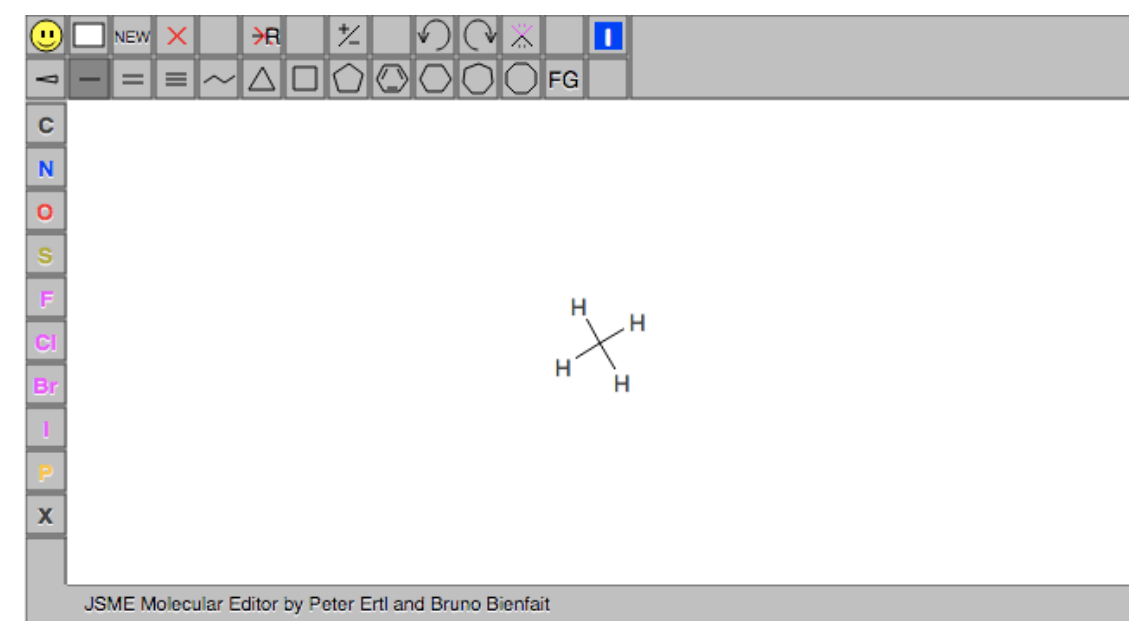

Kuv a 1. JSME:n oletusnäkymä Edumolin sisällä. 


\section{Kemian opetuksen ja oppimisen tukena}

Edumol on kehitetty vastaamaan kemian opetuksen ja oppimisen tarpeita. Sen tavoitteena on olla helppokäyttöinen kemian kouluopetukseen ja korkeakouluopintoihin soveltuva molekyylimallinnusympäristö, joka yhdistää laskennallisen kemian, keminformatiikan, rakennedatatietokannat ja useita kemian sovellusalueita (ks. kuva 2). Edumolin kehittäminen on aina ollut tutkimuspohjaista, eli sen kaikki toiminnallisuudet on suunniteltu kemian opetuksen tutkimuksen pohjalta. Toiminnalliset rajaukset tehtiin jo vanhaa versiota kehitettäessä vuonna 2010. Ne on dokumentoitu julkaisussa Pernaa \& Aksela (2011). Toiminnallisuuksien rajaaminen oli tarpeen, sillä Edumol hyödyntää vain murto-osaa JSmol:n tarjoamista ominaisuuksista. Tutustutaan seuraavaksi tehtyihin valintoihin tarkemmin.

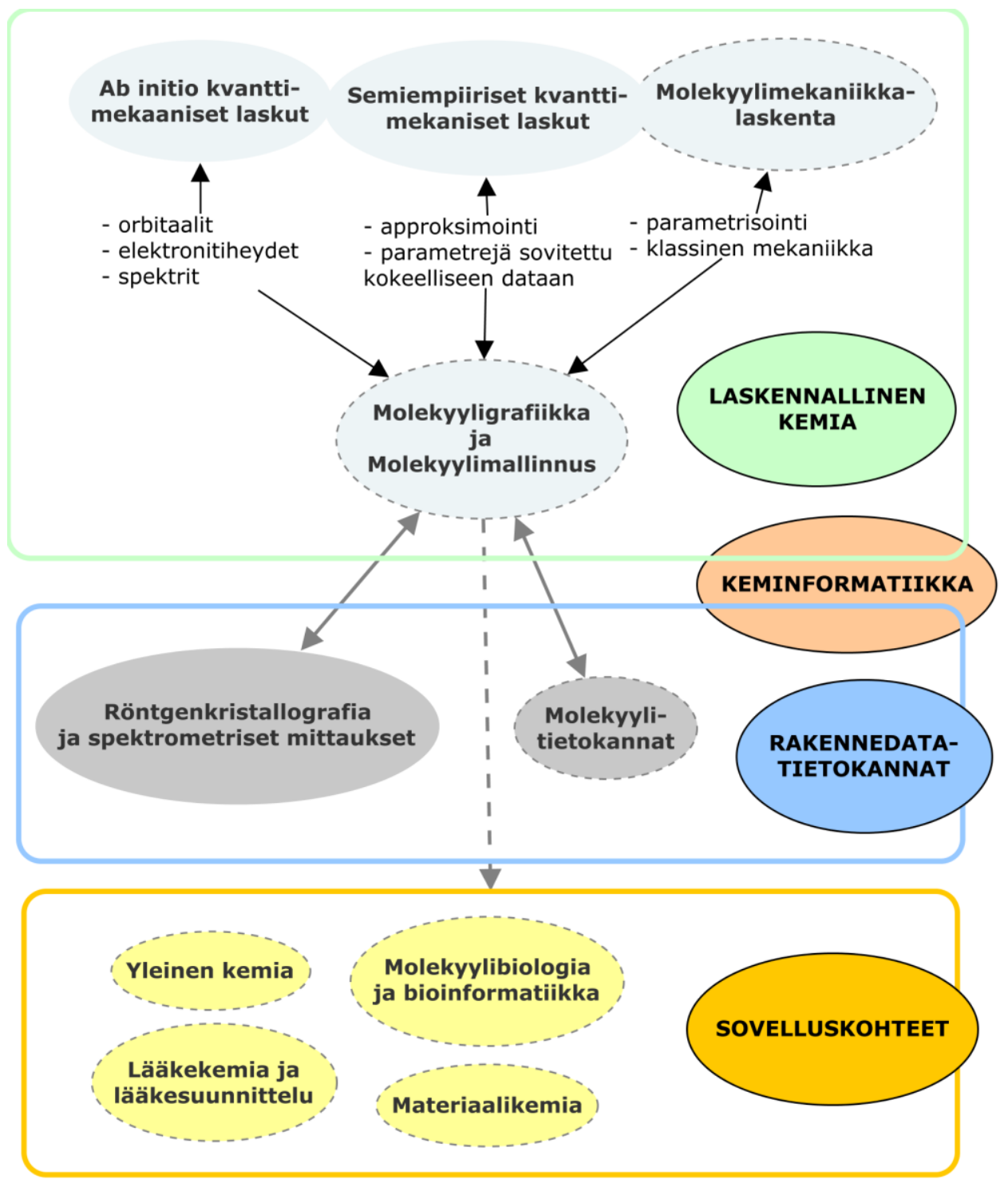

Kuva 2. Edumolin toiminnallisuudet tietokoneavusteisen kemian näkökulmasta tarkasteltuna. Palvelustalöytyvät ominaisuudet on visualisoitu katkoviivalla. (Bladon, Gorton, \& Hammond, 2012, s. 4) 


\subsection{Keminformatiikkaa ja tietokantoja}

Keminformatiikka on kemian sovellusalue, joka yhdistää kemian ja tietotekniikan. Keminformatiikassa ollaan kiinnostuneita kemiallisen informaation tallentamisesta, hakemisesta, esittämisestä sekä suurten informaatiomassojen relaatioiden löytämisestä. (Wild, 2013)

JSmol, jonka päälle Edumol on rakennettu, tarjoaa monipuolisen keminformatiikan rajapinnan. JSmol:n avulla Edumol on yhdistetty kolmeen eri molekyylitietokantaan, jotka valitaan 3D-puolen vetovalikosta (ks. kuva 3). Palvelu käyttää oletuksena NCI-tietokantaa (Small molecules), joka sisältää 250250 rakennetta (National Cancer Institute, 2015). NCI on valittu oletustietokannaksi sen vuoksi, että sen sisältämät rakenteet on optimoitu 2Dtyöskentelyyn ja ne soveltuvat hyvin JSME-editorilla muokattavaksi (JSmol, 2015). NCI:n lisäksi Edumolista voidaan hakea makromolekyylejä Protein Data Bank -palvelusta sekä pieniä molekyylejä PubChem:stä. Huomionarvoista on se, että Protein Data Bank -palvelusta haettuja makromolekyylejä ei voi mallintaa 2D-puolella, koska niissä on liian monta atomia. Edumol ilmoittaa tästä virheilmoituksella.

\begin{tabular}{|l|l|l|}
\hline ammonia & Small molecules & \\
\hline Q Search / IRun & & Macromolecules \\
\hline 3D > 2D & & PubChem \\
\hline Q & & \\
\hline
\end{tabular}

Kuva 3. Valittavana olevat tietokannat.

Molekyylitietokantojen lisäksi Edumolista on yhteys NIST-verkkokirjaan, josta pystyy suorittamaan rakennehakuja molekyylikaavan perusteella (ks. kuva 4). Edumol hakee rakennetta vastaavan molekyylikaavan NCI-tietokannasta, jonka se asettaa NIST-haun hakuparametriksi. Ominaisuus toimii vain, jos NCI-tietokanta on toiminnassa ja visualisoitu rakenne vastaa NCI-palvelusta löytyvää rakennetta.

\section{High resolution}
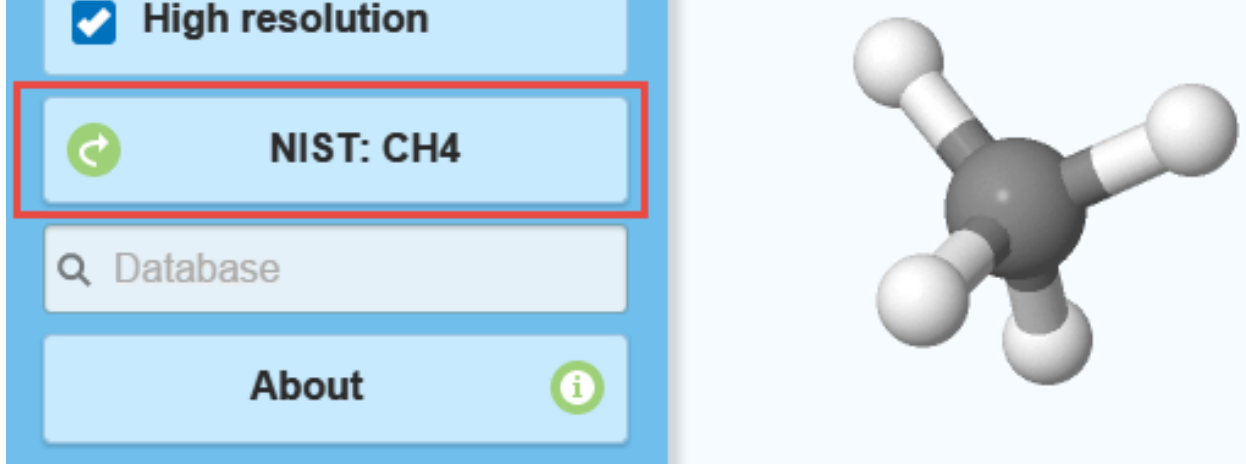

Kuv a 4. NIST-haku löytyyv asemmasta palkista. Esimerkiksi CH4-haku antaa seuraavan hakutuloksen (NIST, 2015). 


\subsection{D-rakentaminen}

Edumolin kehittämisessä on pidetty tärkeänä ominaisuutena mahdollisuutta yhdistää 3Dvisualisoinnit 2D-rakentamiseen. 2D-rakentaminen on toteutettu JSmol:n JSMEintegraatiolla. 2D-työkalut avataan etupaneelin 3D > 2D -painikkeesta (ks. kuva 3), jolloin Edumol siirtää 3D-ikkunassa olevan rakenteen 2D-työpöydälle. 2D-puolella voi esimerkiksi lisätä, poistaa tai muuttaa molekyylin atomeja. Edumol tulostaa myös rakenteen nimen 2Dtyötilan alaosaan, jos rakenne löytyy NCI-tietokannasta. Jos rakenne ei löydy sieltä, niin tulostuu virheilmoitus "Name not found".

2D-puolella voi hakea rakenteita myös suoraan tietokannoista. Aikaisemmin mainittiin, että oletuksena käytetään NCI-tietokantaa, koska sen rakenteet on optimoitu 2Drakentamiseen. Kuvasta 5 näkee esimerkin NCI:n ja PubChem:n rakenteiden välillä.
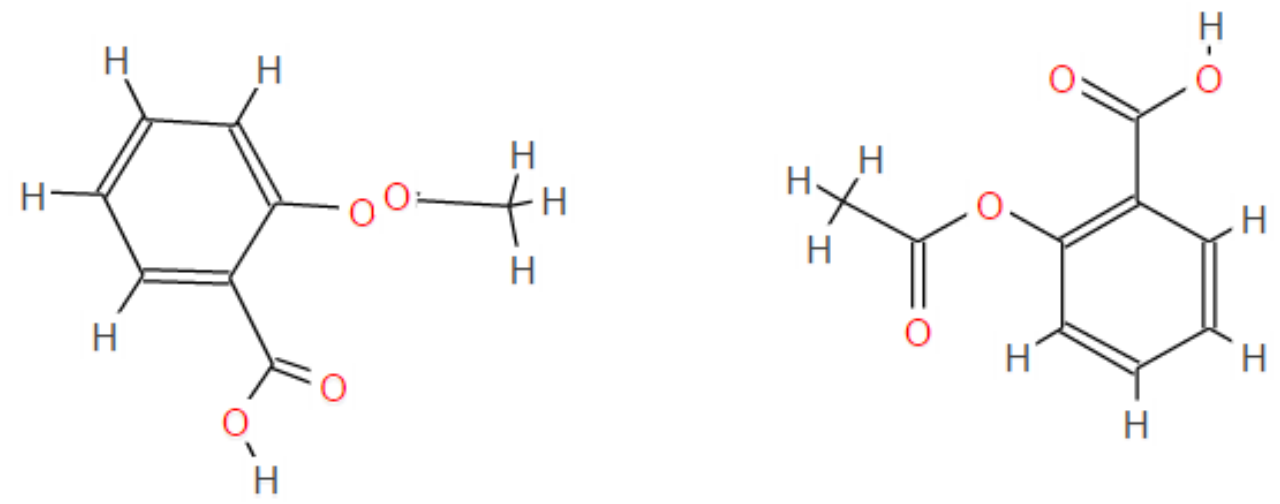

Kuv a 5. Vasen rakenne on noudettu PubChem:stäja oikea 2D-optimoitu rakenne NCItietokannasta.

2D-rakentamisen yhdistäminen $3 \mathrm{D}$-visualisointiin tukee hyvin tutkimuskirjallisuuden suositusta molekyylimallien muokkausmahdollisuudesta. Justi ja Gilbert (2002) suosittelevat opettajille molekyylimallien käytön yhteydessä, että oppilaille tulee antaa mahdollisuus rakentaa omia malleja ja testata niitä. Edumolissa käyttäjä saa vapaasti muokata mallia ja sovellus antaa välitöntä palautetta rakenteesta sen nimen perusteella.

\subsection{Laskenta}

Kuvassa 2 on kuvattu molekyylimallinnuksen roolia tietokoneita hyödyntävän kemian kontekstissa (Bladon ym., 2012, s. 4). Laskennallisen kemian kohdalla on nostettu esille kolme menetelmää, joista Edumol tukee laskennallisesti kaikkein yksinkertaisinta eli molekyylimekaniikkaa. Tämä aiheuttaa Edumolilla tehtävään laskentaan tiettyjä rajoitteita.

Molekyylimekaniikka eli voimakenttämenetelmä on laskennallinen menetelmä, jossa kemiallista systeemiä tarkastellaan klassinen mekaniikan keinoin. Klassisen mekaniikan laskut ovat hyvin yksinkertaisia verrattuna muihin kuvassa 2 mainittuihin laskennallisiin 
menetelmiin (ab initio tai semiempiiriset menetelmät). Molekyylimekaniikassa ei pyritä selvittämään molekyylin elektronista energiaa Schrödingerin yhtälöä ratkaisemalla, vaan molekyylejä ja niiden välisiä vuorovaikutuksia mallinnetaan yksinkertaistetun pallo-jousivuorovaikutuksen avulla. Molekyylimekaniikassa jokaista atomia tarkastellaan itsenäisenä objektina (pallo), jolla on atomisäde, massa ja varaus. Atomien välisiä vuorovaikutuksia kohdellaan jousivoimana. Atomien koot, massat ja varaukset sekä sidosten optimipituudet on määritetty ennalta kokeellisen tai kvanttikemiallisen laskennallisen datan avulla. Yhteen atomiin kohdistuu useita erilaisia voimia, joiden summasta saadaan atomiin vaikuttava kokonaisvoima. Koko systeemin kokonaisenergia Ekok saadaan selville laskemalla yhteen kaikkien atomien välisten vuorovaikutusten energiat kaavan 1 mukaisesti. (Mattila, 2008, s. 16-19)

$$
E_{\mathrm{kok}}=E_{\mathrm{sidos}}+E_{\mathrm{kulma}}+E_{\mathrm{kierto}}+E_{\mathrm{taso}}+E_{\mathrm{vdw}}+E_{\text {sähköstaattinen }}(1)
$$

Kaavasta neljä ensimmäistä energiatermiä mallintavat kovalenttiseen sitoutumiseen liittyvään energiaa. Sidospituus $E_{\text {sidos }}$ on kahden atomin välinen potentiaali, sidoskulma Ekulma on kolmen atomin välinen potentiaali, torsiokulma Ekierto ja tasokulma $E_{\text {taso }}$ mallinnetaan neljän atomin välisellä potentiaalilla (ks. kuva 6). Sidosenergioiden lisäksi voimakentissä otetaan huomioon myös sidoksista riippumattomat sähköstaattiset ja van der Waals -voimat (engl. nonbonded). Ne lasketaan atomeille, jotka eivät vuorovaikuta keskenään neljän ensimmäisen energiatermin kautta. Sähköstaattiset voimat lasketaan atomien varausten eli molekyylien osittaisvarausten avulla. Osittaisvarausmallin avulla voidaan kuvata karkealla tasolla molekyylin sähkökenttää, josta esitän esimerkin myöhemmin kuvassa 10. Van der Waals -voimien laskemiseksi tarvitaan van der Waals -säde, joka on myös ennalta määritetty kokeellisenja laskennallisen datan avulla. Van der Waals voimat kuvaavat atomien elektronirakenteiden välistä vuorovaikutusta. Lähellä olevat atomit hylkivät toisiaan ja kaukana olevat vetävät toisiaan puoleensa. Vdw-termi heikkenee nopeasti atomien etäisyyden kasvaessa (ks. kuva 8). (Mattila, 2008, s. 16-19)
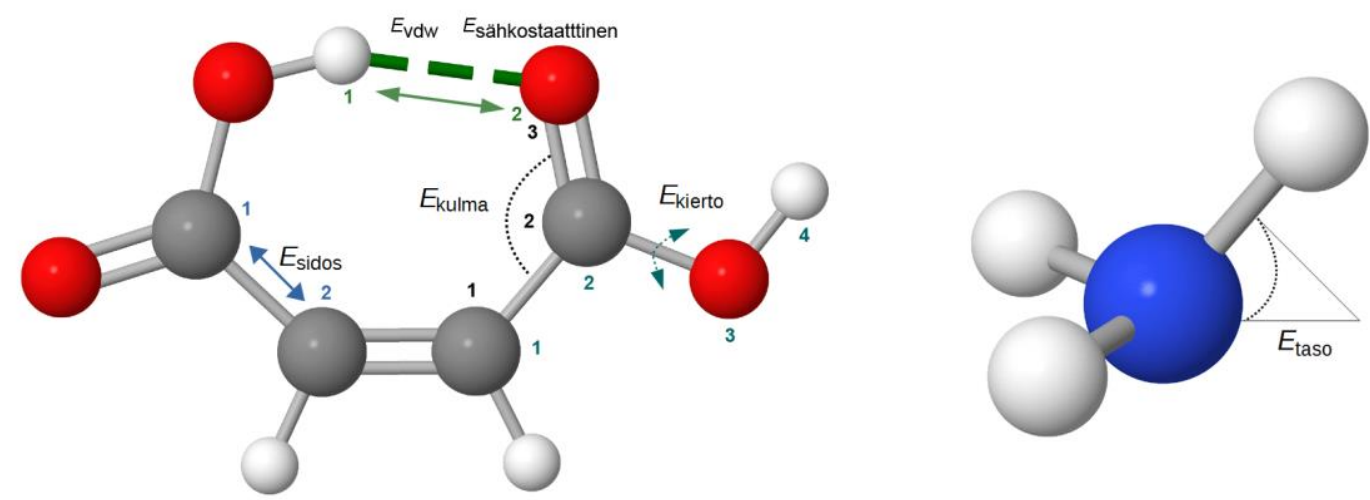

Kuva 6. Sitoutumiseen liittyvät energiatermit. 
Edumolissa molekyylimekaniikan energiafunktion energiatermit voi helposti konkretisoida teoriasta käytäntöön laskemalla jonkin molekyylin energian ja analysoimalla laskennan tuloksia. Tulosliuskassa jokaiselle atomille on annettu järjestysnumero ja se on yhdistetty kemialliseen symboliin, jolloin tuloksia voidaan tarkastella myös atomi- ja sidoskohtaisesti (ks. kuva 7).

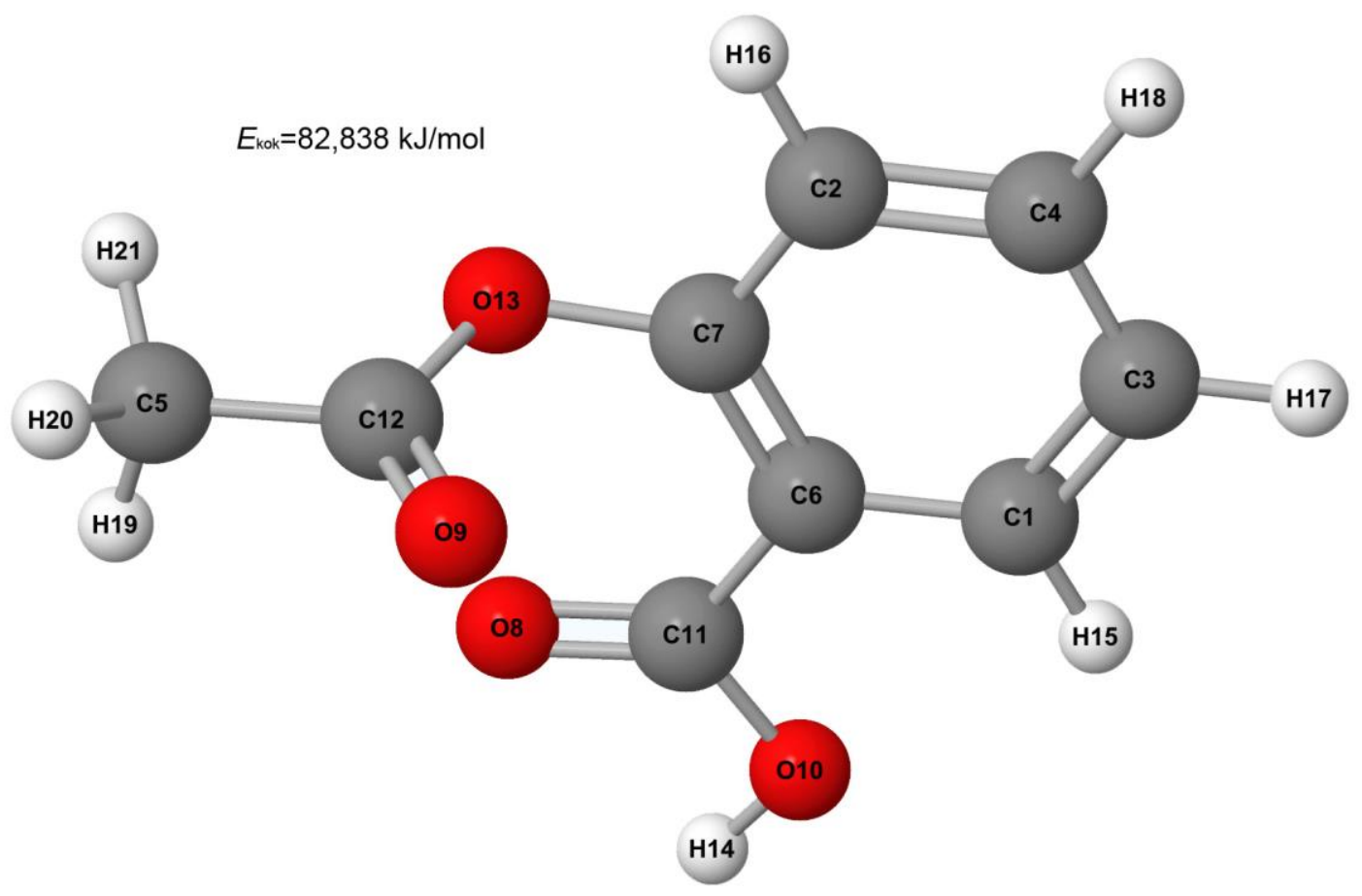

Kuva 7. Edumolissa voi visualisoida atominumerot, jolloin energia-arvoja voidaan tarkastella tulosliuskasta atomikohtaisesti.

Edumolin tulosliuskassa on eritelty jokaisen sidosvenytyksen, sidoskulman, torsiokulman ja tasokulman energia-arvot. Van der Waals -voimista ja sähköstaattisista vuorovaikutuksista on listattu vain osittainen lista. Tulosliuskan avulla kaava 1 voidaan konkretisoida laskemalla yhteen jokaisen energiatermin kokonaisarvot ja vertaamalla sitä ilmoitettuun kokonaisenergiaan (ks. Taulukko 1). 
T aulukko 1. Esimerkki Edumolilla minimoidun aspirïnimolekyylin energia-arvoista.

\begin{tabular}{|c|c|c|}
\hline Yhtälö & Edumolin tulostiedosto & $\mathrm{kJ} / \mathrm{mol}$ \\
\hline Esidos & Total bond stretching energy & 12,009 \\
\hline Ekulma & Total angle bending energy & 34,060 \\
\hline Ekierto & Total torsional energy & 25,100 \\
\hline Etaso & Total out-of-plane bending energy & 0,114 \\
\hline Evdw & Total van der waals energy & 97,233 \\
\hline Esähköstaattinen & Total electrostatic energy energy & $-85,678$ \\
\hline$E_{\text {kok }}$ & Total MMFF energy & 82,838 \\
\hline
\end{tabular}

\section{Geometrian optimointi}

Molekyylimekaniikassa molekyylien maailma on siis yksinkertaistettu palloista ja jousista koostuvaksi klassisen mekaniikan avulla käsiteltäväksi systeemiksi. Molekyylimekaniikassa ei selvitetä elektronista energiaa, joten sillä ei voi laskea tai visualisoida orbitaaleja, elektronitiheyttä tai kemiallisia reaktioita, mutta ne sopivat erinomaisesti molekyylin geometrian optimointiin. Geometrian optimoinnissa etsitään kaavassa 1 esitetyille energiatermeille rakenne, joka vastaa energiaminimiä. Käytännössä tämä tarkoittaa sitä, että molekyylimallinnusohjelmisto muuttaa sidoskulmia ja sidospituuksia siten, että alimman energian geometria löytyy (ks. kuva 8). (Mattila, 2008, s. 16-19)

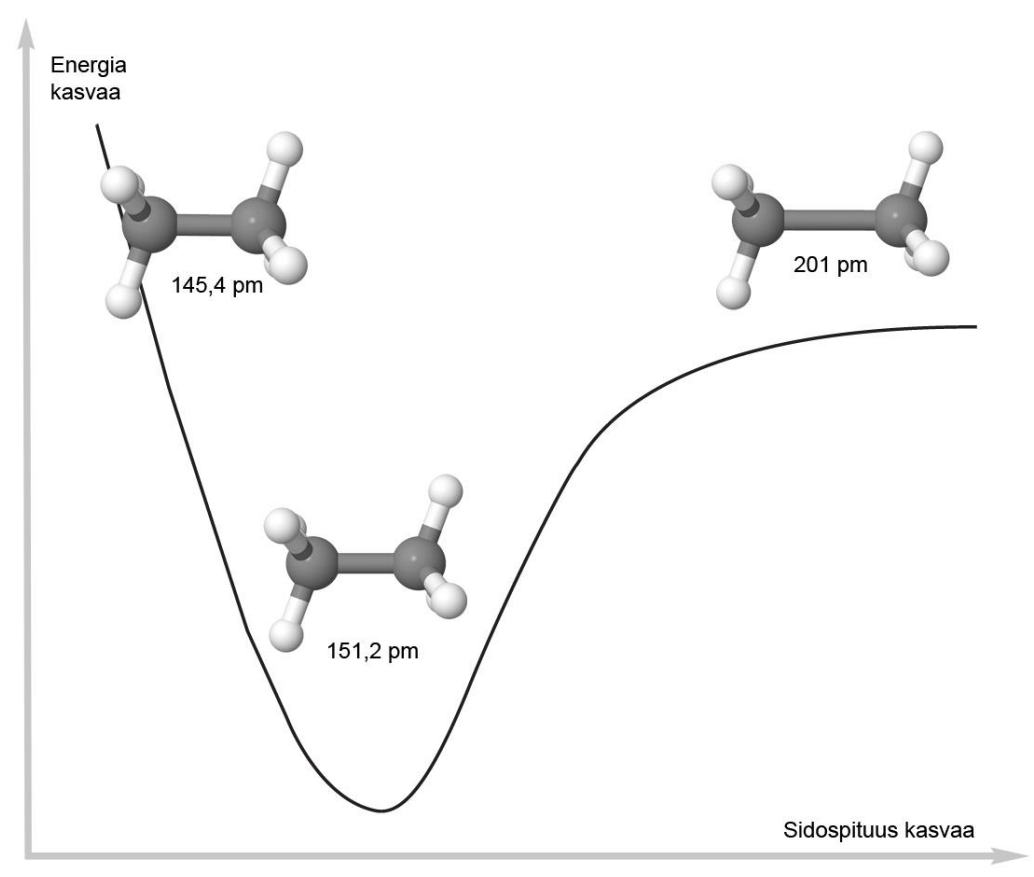

Kuva 8. Etaanin sidospituuden optimointia. Alin energiatila saavutetaan sidoksen optimipituudella. Oheinen kuva on vain karkea havainnollistus ja sen vuoksi energia-arvoja ei ole kirjattu kuvaajaan. 
Geometrian optimoinnin avulla löydetään siis molekyyligeometrioita, joiden oletetaan vastaavan mahdollisimman hyvin luonnossa esiintyviä rakenteita. Tämä perustuu oletukselle, että luonnossa molekyylit pyrkivät mahdollisuuksien mukaan olemaan energeettisesti alimmassa konformaatiossa. Tämä mahdollistaa sen, että menetelmää voidaan käyttää ennustamaan ja validoimaan kokeellista dataa ja tukemaan sen avulla tehtäviä päätelmiä. Optimointia voidaan käyttää pienten molekyylien rakenteiden optimointiin, mutta se voidaan suorittaa nopeasti suurillekin systeemeille (esim. proteiinitelakointi). (Mattila, 2008, s. 16-19)

Nopeuden mahdollistaa oletus, jonka mukaan voimakentän ennalta määriteltyjen mallimolekyylien parametrejä voidaan hyödyntää kohtuullisen tarkasti samankaltaisten rakenteiden optimointiin. (Mattila, 2008, s. 16-19) Ohjelmistotasolla MMFF94voimakentän parametrisoitua dataa hyödynnetään siten, että ohjelmisto tuottaa molekyylirakenteesta ensin yksityiskohtaisen koneella luettavan esityksen, jossa on eritelty kaikki laskuissa huomioon otettavat atomit, atomien koordinaatit, sidokset ja kulmat. Seuraavaksi ohjelmisto vertaa tarvittavia rakenteita voimakentän parametreihin ja etsii, että löytyykö tarvittavia tietoja voimakentästä vai lasketaanko ne itse. Jos tieto löytyy, niin ohjelmisto asettaa ne energiafunktioon. Voimakentässä parametrit on aseteltu loogisesti siten, että niitä voidaan hakea konehaulla nopeasti. (Halgren, 1996)

Edumoliin haetut rakenteet kannattaa aina optimoida, sillä ensisijaisesti hyödynnetyn NCI-tietokannan kaikkia molekyylejä ei ole optimoitu. Esimerkiksi eteenin kaksoissidoksen optimoinnissa $\mathrm{H}-\mathrm{C}-\mathrm{H}$-sidoskulman arvo muuttuu $120^{\circ} \rightarrow 117,9^{\circ}, \mathrm{ja} \mathrm{C}=\mathrm{C}$-sidospituuden arvo $131 \mathrm{pm} \rightarrow 133,5 \mathrm{~nm}$. Kokeellinen arvo eteenin $\mathrm{C}=\mathrm{C}$-sidokselle on 133,05 pm. Geometrian optimointi Edumolissa antaa siis hieman tarkemman arvon. Esimerkissä muutos on pieni, mutta optimoinnin merkitys korostuu silloin, kun molekyylejä rakennetaan 2D-puolella ja tuodaan visualisoitavaksi 3D-puolelle. Rakentamisen jäljiltä sidoskulmat ja sidospituudet voivat olla todella kaukana kokeellisista arvoista. Jos taas haluaa molekyyleilleen tarkempia teoreettisia arvoja, niin ne kannattaa hakea PubChem-tietokannasta. PubChem:ssä rakenteet on valmiiksi optimoitu MMFF94-voimakentällä asiantuntijoiden toimesta. Esimerkiksi eteenin C=C-sidoksen pituus on oletusarvoisesti 133,4 pm.

Edumol hyödyntää pääosin samaa MMFF94-voimakenttää, kuin PubChemtietokannassakin on käytetty. MMFF94 on kehitetty pienten orgaanisten molekyylien mallintamiseen. (Halgren, 1996) Jos optimoitavasta molekyylistälöytyy atomeja joita ei ole sisällytetty MMFF-voimakenttään, vaihtaa Edumol automaattisesti UFF-voimakenttään. UFF on hieman epätarkempi, koska sitä ei ole kehitetty mihinkään tiettyyn tarkoitukseen. Se on nimensä mukaisesti Universal Force Field. (JSmol, 2015)

Molekyylejä optimoitaessa täytyy ottaa huomioon se, että ohjelmisto lopettaa optimoinnin ensimmäisen energiaminimin löytyessä. Tämä ei välttämättä ole globaali minimi (vrt kuva 8). Pienten molekyylien kohdalla on helppo testata kaikki konformeerit globaalin minimin löytämiseksi, mutta isompien rakenteiden kanssa niitä on niin paljon, että 
manuaalinen läpikäynti on todella hankalaa. Suurien konformaatiomäärien analysoimiseksi useisiin ohjelmistoihin on kehitetty tarkoitukseen soveltuvia konformaation analysointi toimintoja (Mattila, 2008, s. 16-19), mutta Edumolissa niitä ei ole. Edumolissa energian minimointi toteutetaan jyrkimmän suunnan -menetelmällä (engl. Steepest descent). Optimoinnin tulosliuskassa optimointiprosessi esitetään seuraavasti:"

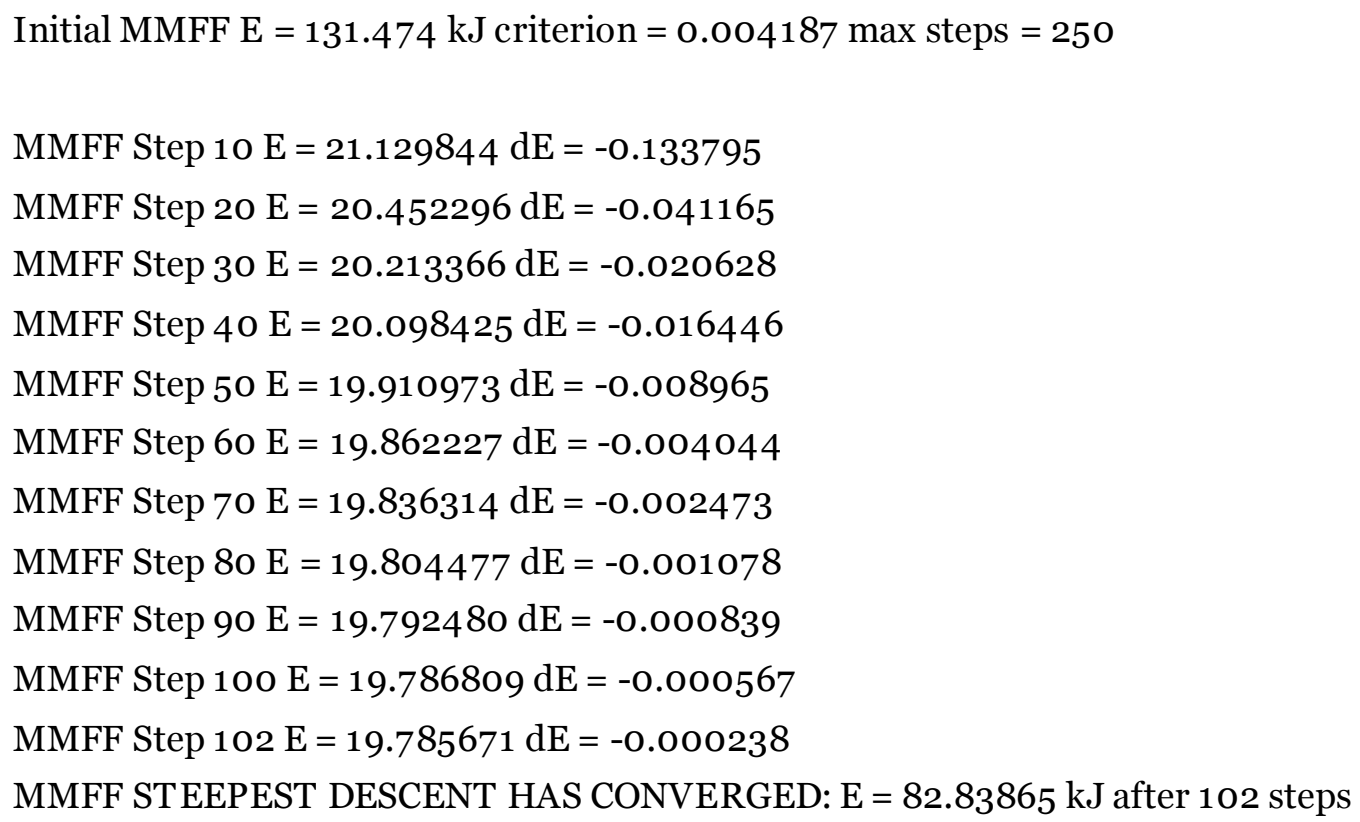

\subsection{Visualisointi}

Edumol soveltuu parhaiten molekyylien visualisointiin, sillä siihen JSmol on alun perin rakennettu. Edumoliin voi viedä mitä tahansa molekyylidataa ja Jsmol-kirjasto osaa sitä käsitellä. Tarkastellaan seuraavaksi Edumoliin sisällytettyjä visualisointityökaluja.

\subsubsection{Molekyylimallien eri esitystavat}

Tietokoneiden avulla samaa molekyyliä voi tarkastella eri esitystavoilla. Edumol tukee yleisimpiä mallien eri esitystapoja (ks. kuva 9).

- Tikkumalli antaa tietoa sidoksista, mutta ei molekyylin muodosta, koosta tai atomien sijainnista.

- Putkimalli on samankaltainen kuin tikkumalli, mutta siinä sidokset ovat hieman paksumpia. Tätä käytetään usein esim. makromolekyylien visualisoinneissa.

- Pallotikkumalli antaa tietoa sidostyypeistä ja atomien sijainnista.

- Kalottimalli kuvaa molekyylin avaruudellista muotoa ja kokoa, mutta ei välitä tietoa sidostyypeistä. Kalottimallia ei kannata käyttää silloin, kun tarkoituksena on mitata sidoskulmia ja -pituuksia. 


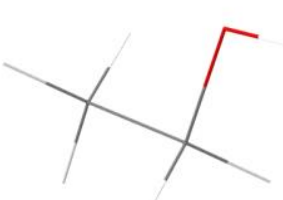

TIKKUMALLI

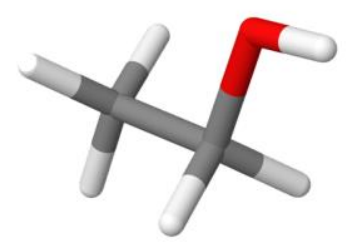

PUTKIMALLI

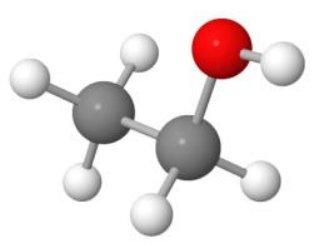

PALLOTIKKUMALLI

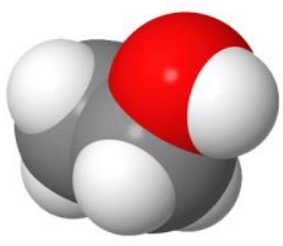

KALOTTIMALLI

Kuv a 9. Molekyylimallien eri esitystavat.

\subsubsection{Varausjakaumatja elektrostaattinen potentiaalipinta}

Edumolilla voidaan laskea molekyylin varausjakauma ja visualisoida se elektrostaattisena potentiaalipintana. Tämä ominaisuus on hyvin tärkeä. Varausjakauman avulla voidaan analysoida, mikä osa molekyylistä on reaktiivinen ja miten se mahdollisesti käyttäytyy. Elektrostaattinen potentiaalipinta on keino esittää elektronijakauma selkeässä visuaalisessa muodossa. Visualisointi antaa tietoa myös molekyylin koosta ja muodosta. Esimerkiksi kuvan 10 etanolimolekyylissä elektronegatiivisimmalla atomilla, happiatomilla on negatiivisin osittaisvaraus ja sen ympärillä on korkein elektronitiheys. $\mathrm{OH}-\mathrm{ryhmä} \mathrm{on} \mathrm{myös}$ etanolimolekyylin reaktiivisin osa. (Bottyan, 2015)

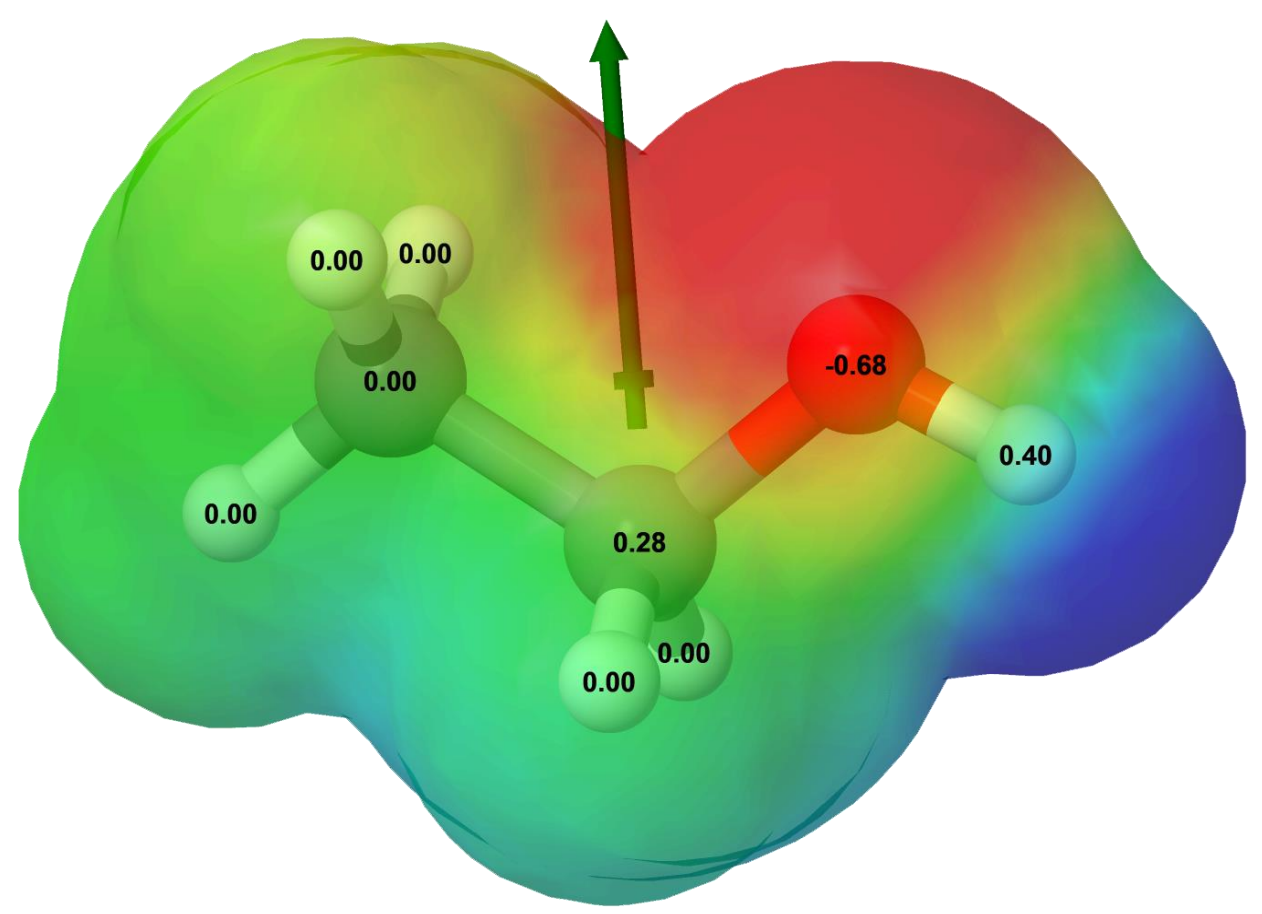

Kuva 10. Etanolimolekyylin osittaisvaraukset ja läpinäkyvä elektrostaattinen potentiaalipinta. Hapella on negatiivisin o sittaisvaraus ja sen ympärillä on punaisella visualisoitu elektronitihentymä.Vihreä dipolivektori o soittaa sähkökentän voimakkuuden ja suunnan positiivisesta negatiiviseen. 


\subsubsection{Mittaaminen}

Edumolissa on kosketusnäytöille optimoidut mittaustyökalut. Mittaustyökaluilla voi mitata sidospituuksia, sidoskulmia ja neljän atomin muodostamia tasokulmia. Mittaustyökalut aktivoidaan oikeasta palkista (ks. kuva 11).

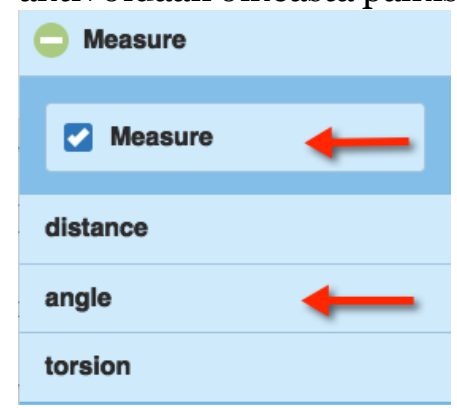

Kuva 11. Edumolin mittaustyökalut löytyvät oikeasta palkista. Ensin laitetaan mittaaminen päälle, jonka jälkeen valitaan haluttu toiminto.

\subsection{Tiedon tallennus ja prosessointi}

Edumolissa on hyvin monipuoliset tiedonhallintatyökalut (ks. kuva 12). Ensinnäkin tiedoston voi tallentaa ja avata uudestaan, mikä on poikkeuksellista verkkopohjaisille kemian mallinnusohjelmistoille. Tämä mahdollistaa opettajille ja oppijoille vaativienkin visualisointiaktiviteettien toteuttamisen, tallentamisen ja jatkoprosessoinnin. Edumolissa voi avata lähes jokaista kemiallisten rakenteiden tiedostotyyppiä, mitä alalle on kehitetty. Monipuolinen tiedostotuki on Edumolin hyödyntämän Jsmol-kirjaston vahvuus. Kuten aikaisemmin mainittiin, JSmol on ensisijaisesti kehitetty visualisointiohjelmistoksi. (Jsmol, 2015)

Molekyylin voi myös tallentaa kuvana joko työpöydän mukaisessa koossa tai korkearesoluutiomuodossa 2000*2000 pikseliä. Kuvat tallennetaan läpinäky vällä taustalla png-muodossa, mikä tekee niiden upottamisen muun muassa PowerPoint-kalvoihin helpoksi. Lisäksi tiedoston voi viedä mol-tekstitiedostoksi ja avata molekyylien piirtoohjelmistoissa, tai $3 \mathrm{D}$-malliksi, jonka voi vaikka tulostaa $3 \mathrm{D}$-tulostimella konkreettiseksi molekyylimalliksi.

\begin{tabular}{|l|}
\hline File \\
\hline Open \\
\hline Save \\
\hline Export png \\
\hline Export png (HQ) \\
\hline Export mol \\
\hline Export X3D \\
\hline
\end{tabular}

Kuva 12. Edumolin tiedostovalikko. 


\section{Yhteisöllisyys}

Edumol on kehitetty yhteisölliseksi palveluksi, joka antaa käyttäjilleen mahdollisuuden verkostoitua ja saada tukea. Edumol on yhdistetty kahteen sosiaalisen median verkkopalveluun (Flickr ja Facebook), joihin siirrytään vasemman palkin ikoneiden kautta (ks. kuva 13).
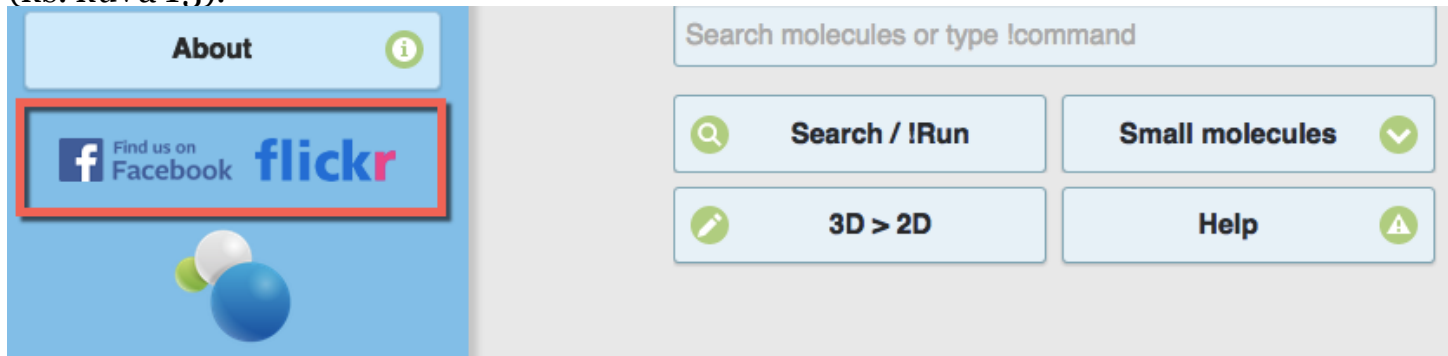

Kuva 13. Yhteys sosiaaliseen mediaanlöytyyvasemmasta palkista.

1. Edumolin Flickr-profiilissa jaetaan ilmaisia molekyylikuvia Creative Commons Nimeä-JaaSamoin -lisensillä (CC BY-SA). Kuvat tarjotaan aina korkealaatuisina sen vuoksi, että koulut, yhdistykset ja yritykset voisivat käyttää niitä painetuissa ja digitaalisissa mediaprojekteissa ja markkinointimateriaaleissa (ks. esim. kuvasta 14). Kuvien lisenssi antaa luvan teoksen muokkaamiseen ja kaupalliseen käyttöön, kunhan muokatussa teoksessa vain viitataan alkuperäislähteeseen ja työ jaetaan samalla CC BY-SA -lisenssillä. Flickr-palvelun yhteisöllisyys rakentuu kuvamedian ympärille. Kuvia voi kommentoida, suositella tai edelleen jakaa. Käyttäjä voi myös tehdä oman Flickr-palvelun ja alkaa seuraamaan Edumolia, jolloin hän saa viestin uudesta kuvasta. Edumol-ylläpito lataa palveluun myös käyttäjien tekemiä kuvia, jotka voi lähettää ylläpidolle osoitteeseen images@edumol.fi.

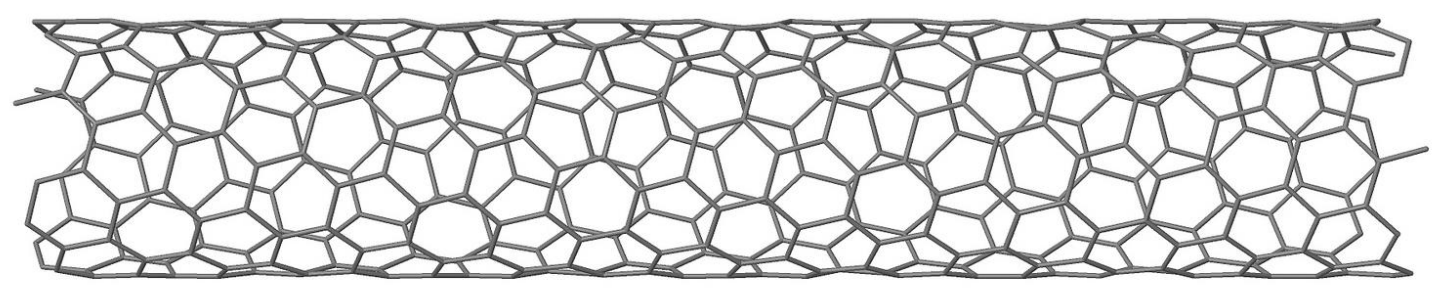

Kuva 14. Nanoputk $i$-kuva Edumolin Flickr-tilistä.

2. Edumolin Facebook-sivu on tiedotus- ja tukikanava, jossa ylläpito tiedottaa sovelluksen päivityksistä ja mahdollisista palvelukatkoista. Esimerkiksi jos vaikka jokin Edumolin hyödyntämistä tietokannoista on epäkunnossa ja se vaikuttaa palvelutasoon, niin siitä saa tiedon Facebook-sivun kautta. Sieltä saa myös suoran yhteyden käyttäjätukeen. Facebook-kanavaa kannattaa käyttää, koska silloin myös muut käyttäjät näkevät kysymyksen ja vastauksen. Tämätekee ongelmanratkaisusta ja palvelun käyttämisestä yhteisöllistä, sillä käyttäjät voivat samalla verkostoitua ja jakaa kokemuksia. 


\section{Pohdinta ja jatkokehittäminen}

Artikkelissa kuvattiin Edumolin historia, nykyisen version kehittäminen ja kemian opetusta tukevat ominaisuudet. Palvelu ja sen tutkimuspohjaiset ominaisuusrajaukset on otettu opettajien keskuudessa hyvin vastaan ja sen käyttäjämäärät ovat tasaisessa nousussa. Palvelutaso Edumolin päässä on pystytty pitämään 100 \%:na, mutta NCI-tietokannan toimivuudessa on esiintynyt ajoittaisia ongelmia. NCI-palvelun toimivuus vaikuttaa Edumolin toimivuuteen, sillä NCI:tä käytetään 3D-puolella molekyylikaavan ja 2D-puolella molekyylinimen hakemiseen. Tämä ongelma tullaan ratkaisemaan jollain aikataululla siten, että Edumol tarkistaa onko NCI ylhäällä. Jos ei ole niin edellä mainitut toiminnot kytketään pois päältä, että palvelun käyttöä voidaan jatkaa.

Tulevaisuudessa palvelua tullaan kehittämään opettajien tarpeiden mukaisesti. Tämä tarkoittaa sitä, että palvelun käyttäjät voivat tehdä ehdotuksia ominaisuuksista ja ne toteutetaan harkinnan mukaan. Teknisen kehittämisen lisäksi palvelun ympärillä aletaan toteuttaa kemian opetuksen tutkimusta yhteistyössä eri korkeakoulujen kanssa. Yksi mielenkiintoisimmista tulevaisuuden tutkimusaiheista on $3 \mathrm{D}$-tulostaminen, jonka on ennustettu kasvavan todella käytetyksi teknologiaksi yhteiskunnassa. 3D-tulostus on toistaiseksi vähän tutkittu aihealue kemian opetuksen tutkimuksessa, ja sen mahdollisuuksista kemian oppimisen tukena tarvitaan lisää tietoa. 


\section{Lähteet}

Aksela, M., \& Lahtela-Kakkonen, M. (2001). Molekyylitason teknologiaa opetuksessa. Kemia-Kemi, 28(3), 200-203.

Aksela, M., \& Lundell, J. (2008). Computer-based molecular modelling: Finnish school teachers' experiences and views. Chemistry Education Research and Practice, 9(4), 301-308. http://doi.org/10.1039/B818464J

Bienfait, B., \&Ertl, P. (2013). JSME: a free molecule editor in JavaScript. Journal of Cheminformatics, 5(1), 24. http://doi.org/10.1186/1758-2946-5-24

Bladon, P., Gorton, J. E., \& Hammond, R. B. (2012). Molecular modelling: computationalchemistry demystified. Cambridge: RSC Publishing.

Bottyan,T. (2015). Electrostatic Potential maps. Noudettu 27. syyskuuta 2015, osoitteesta http://chemwiki.ucdavis.edu/Theoretical_Chemistry/Chemical_Bonding/General_Principles_of _Chemical_Bonding/Electrostatic_Potential_maps

Edumol. (2015). EDUMOL. Noudettu 2. syyskuuta 2015, osoitteesta http://edumol.fi

Halgren, T. A. (1996). Merck molecular force field. I. Basis, form, scope, parameterization, and performance of MMFF94. Journal of Computational Chemistry, 17(5-6), 490-519. http://doi.org/10.1002/(SICI)1096-987X(199604)17:5/6<490::AID-JCC1>3.0.CO;2-P

Hanson, R. (2012). Java-less Jmol = = "JSmol”. Noudettu 22. elokuuta 2015, o soitteesta http://sourceforge.net/p/jmol/mailman/message/29960031

Jmol. (2015). Jmol: an open-source Java viewer for chemical structures in 3 D. Noudettu 22. elokuuta 2015, osoitteesta http://www.jmol.org

JSmol. (2015). Jmol Wiki - JSmol. Noudettu 22. elokuuta 2015, o soitteesta http://wiki.jmol.org/index.php/JSmol

Justi, R., \& Gilbert, J. (2002). Models and modelling in chemical education. Teoksessa J. K. Gilbert, R. Justi, D. Treagust, O. de Jong \& J. van Driel (toim.), Chemicaleducation: Towardsresearchbased practice (s. 47-68). Dordrecht: Kluwer Academic Publishers.

Mattila, K. (2008). Voimakenttämenetelmät ja molekyylidynamüikka. Teoksessa J. Blomqvist\&T. Kurten(toim.), Ongelmasta ratkaisuun -CSC:n kemian mallinnusopas (1. p., s.16-26). Espoo: CSC - Tieteellinen laskenta Oy.

NCBI. (2015). The PubChem Project. Noudettu 2. syyskuuta 2015, osoitteesta https://pubchem.ncbi.nlm.nih.gov

NIST. (2015). Search Results: CH4. Noudettu 10. syyskuuta 2015, osoitteesta http://webbook.nist.gov/cgi/cbook.cgi?Formula=CH4

Pernaa, J., \&Aksela, M. (2011). Kehittämistutkimus: Kemiankouluopetukseen soveltuvan molekyylimallinnusympäristön kehittäminen. Teoksessa M. Aksela, J. Pernaa, \& M. Happonen (toim.), Kansainvälinen kemian vuosi: Kemia osaksihyvää elämää (s.110-121). Helsinki: Kemian opetuksen keskus.

Pernaa, J., \&Aksela, M. (2013). Sähköisten kemian oppimisympäristöjen historia, nykytilaja tulevaisuus. Lumat, 1(4), 435-456.

RCSB PDB. (2015). RCSB Protein Data Bank - RCSB PDB. Noudettu 2. syyskuuta 2015, o soitteesta http://www.rcsb.org/pdb/home/home.do

The jQuery Foundation.(2015).jQuery Mobile. Noudettu 2. syyskuuta 2015, osoitteesta https://jquerymobile.comWild, D. (2013). Introducing Cheminformatics. Omakustanne. http://cheminfov.informatics.indiana.edu/djwild/ic/. 